九州大学学術情報リポジトリ

Kyushu University Institutional Repository

\title{
Application of Gas-phase 0xygen Electrode to the Measurement of Photosynthetic Potential in Ipomoea batatas Leaves
}

\section{Agarie, Sakae}

Laboratory of Practical Botany, Faculty of Agriculture, Kyushu University

Morokuma, Masahiro

Laboratory of Practical Botany, Faculty of Agriculture, Kyushu University

Uchida, Hideki

Laboratory of Practical Botany, Faculty of Agriculture, Kyushu University

Kubota, Fumitake

Laboratory of Practical Botany, Faculty of Agriculture, Kyushu University

他

https://doi.org/10.5109/24054

出版情報：九州大学大学院農学研究院紀要. 38 (3/4)，pp.225-230，1994-03. Kyushu University バージョン：

権利関係 : 


\title{
Application of Gas-phase $\mathbf{O x y g e n ~ E l e c t r o d e ~ t o ~ t h e ~ M ~ e a s u r e m e n t ~}$ of Photosynthetic Potential in Ipomoea batatas Leaves
}

\author{
Sakae Agarie, Masahiro Morokuma, Hideki Uchida, \\ Fumitake Kubota and Waichi Agata \\ Laboratory of Practical Botany, Faculty of Agriculture, \\ Kyushu University 46-01, Fukuoka 812, Japan
}

(Received January 7, 1994)

\begin{abstract}
A gas-phase $\mathrm{O}_{2}$ electrode was used to determine the photosynthetic potential of Ipomoea batatas leaves. The $\mathrm{O}_{2}$ evolution rates (OER) were measured at different combinations of $\mathrm{CO}_{2}$ concentration $\left(\left[\mathrm{CO}_{2}\right]\right)$, pre - illumination period and water status of leaf, and compared to the values of $\mathrm{CO}_{2}$ assimilation rate (CAR) measured by infra-red gas analyzer (IRGA). The results obtained were as follows; The optimum $\left[\mathrm{CO}_{2}\right]$ for OER measurement was in the range of $5 \%$ to $10 \%$. The photosynthetic activation of sweet potato leaves required a $10-\mathrm{min}$ pre-illumination of $1000 \mu \mathrm{molm}^{-2} \mathrm{~s}^{-1}$. The OER of detached leaf disc with leaf water potential $\left(\psi_{\mathrm{w}}\right)$ above-O.8 $\mathrm{MPa}$ maintained a maximal level for $80 \mathrm{~min}$. The measurements of OER showed a high correlation with CAR measured by IRGA in the atmospheric air. When the measurement condition was controlled as mentioned above, the photosynthetic potential of Ipomoea batatas leaves can be measured by the gas-phase $\mathrm{O}_{2}$ electrode method, and this method is considered to have a wide application to photosynthetic studies on other plants.
\end{abstract}

\section{INTRODUCTION}

The rate of whole leaf photosynthesis is usually monitorred by infra-red gas analyzer (IRGA), which is expensive and requires skilled techniques for measurement procedures. In addition, the photosynthetic rate $(\mathrm{Pn})$ obtained by IRGA is often significantly affected by stomatal movement (Gaastra, 1959; Hanson and Hitz, 1982; Ishihara et al., 1972).

In sweet potato (Ipomoea batatas) leaves, the expression of potential $\mathrm{Pn}$ is often limited by stomatal closure resulting from environmental factors. Therefore, for evaluation of potential $\mathrm{Pn}$, it is necessary to use a technique which can directly measure Pn of mesophyll tissues without stomatal limitation.

A method of overcoming stomatal limitation is to raise $\mathrm{CO}_{2}$ concentration $\left[\mathrm{CO}_{2}\right]$ in the ambient air sufficiently to facilitate $\mathrm{CO}$, diffusion into mesophyll. The oxygen electrode has stable sensitivity under very high [CO,] conditions. It is possible to measure Pn saturated with $\mathrm{CO}_{2}$. However, the conventional liquid-phase measurement with small tissue slices is less sensitive in Pn detection than IRGA, and the values obtained with the liquid-phase $\mathrm{O}_{2}$ electrode are usually very low (Ishihara et al., 1979; Ishii et al., 1977; Jones and Osmond, 1973; Yamashita et al., 1978).

The leaf -disc $\mathrm{O}_{2}$ electrode (gas-phase system) also has stable sensitivity at very high $\left[\mathrm{CO}_{2}\right]$ and can measure Pn (Delieu and Walker, 1981 and 1983) at a precise level as obtained by conventional IRGA. The values obtained with the $\mathrm{O}_{2}$ electrode are considered to be a maximal rate at which photorespiration is almost entirely suppressed (Delieu and Walker, 1981). In addition, the apparatus is simple and inexpensive, and 
very easy to operate. These advantages indicate that the apparatus can be a useful means of evaluating photosynthesis in Ipomoea batatas leaves.

However, some technical problems have been pointed out for the measurement procedure because a leaf was detached and Pn was measured at very high $\left[\mathrm{CO}_{2}\right]$ in the apparatus. In addition, some pre - conditionings are required prior to the start of measurement.

The objective of this work is to know a proper usage of the gas-phase $\mathrm{O}_{2}$ electrode to determine the photosynthetic potential of Ipomoea batatas leaves. $\mathrm{O}_{2}$ evolution rates (OER) were measured at different combinations of $\left[\mathrm{CO}_{2}\right]$ levels, pre - illumination periods and water status of leaves, and compared with the values measured by IRGA methods.

\section{MATERIAL AND METHODS}

\section{Plant material}

Young shoots of Ipomoea batatas Lam. cv. Koganesengan were transplanted in $10,000 \mathrm{~cm}^{3}$ plastic pots containing sandy soil in the middle of April 1992 and grown in a green house for two months. Before transplanting, chemical fertilizers were applied, 2.0 $\mathrm{g}$ per pot of $\mathrm{N}, \mathrm{P}_{2} \mathrm{O}_{5}$ and $\mathrm{K}_{2} \mathrm{O}$. The fully expanded forth to sixth leaves from the top were used for measurement. The epidermis was peeled according to the method of Kubota et al. (1991).

\section{Gas exchange measurements}

1. $\mathrm{O}_{2}$ evolution rate

Measurements were made with a leaf disc oxygen electrode system (Hansatech LD $2 / 2$; Delieu and Walker, 1981) connected to a gas mixing system. The $\left[\mathrm{CO}_{2}\right]$ in the chamber was controlled by mixing pure $\mathrm{N}_{2}, \mathrm{O}_{2}$ and $\mathrm{CO}_{2}$ gas with a gas mixer (Kojima, GM-3A). The temperature of the leaf chamber was maintained at $29^{\circ} \mathrm{C}$ by circulating water from a water bath to the water jacket of the chamber. The air was moistened to keep relative humidity higher than $90 \%$. Each leaf disc $\left(10 \mathrm{~cm}^{2}\right)$ was pre-conditioned in the chamber containing the air with controlled $\left[\mathrm{CO}_{2}\right]$ at a photon flux density (PFD) of $1000 \mu \mathrm{molm}^{-2} \mathrm{~s}^{-1}$ for about $15 \mathrm{~min}$.

2. $\mathrm{CO}_{2}$ assimilation rate

$\mathrm{CO}_{2}$ assimilation rate (CAR) of an intact peeled leaf was measured with a portable photosynthesis measurement system (ADC, SPB-H3) in the adjacent part of a leaf used for the OER measurement. Measurements were taken in the atmospheric normal air at a humidity of $66.2 \pm 0.23 \%$, PFD of $1618 \pm 24.4 \mu$ nnolm $^{-2} \mathrm{~s}^{-1}$ and leaf temperature of $32.8 \pm 0.07^{\circ} \mathrm{C}$.

\section{Measurement of leaf water potential}

Leaf water potential $\left(\psi_{\mathrm{w}}\right)$ was measured in the same leaf disc immediately following the measurement of OER by a thermocouple psychrometer (Wesco, C-52). 


\section{RESULTS AND DISCUSSION}

Figure 1 shows OER of the leaf discs with and without epidermis as affected by [C $\mathrm{O}_{2}$ ]. In the control (unpeeled) leaf, OER increased with increase in $\left[\mathrm{CO}_{2}\right]$ from $0.5 \%$ to $5 \%$. This indicates that OER was inhibited by $\mathrm{CO}$, starvation resulting from stomata1 closure at less than $5 \%\left[\mathrm{CO}_{2}\right]$. There was no further increase in OER with increase in $\left[\mathrm{CO}_{2}\right]$ from $5 \%$ to $10 \%$. The OER curve had a peak at about $5 \%\left[\mathrm{CO}_{2}\right]$. The leaf seemed likely to be saturated with $\mathrm{CO}_{2}$ under $\left[\mathrm{CO}_{2}\right]$ conditions over 5\%. As $\left[\mathrm{CO}_{2}\right]$ increased to $25 \%$, OER decreased to about $70 \%$ of the maximal rate. This OER decrease suggests that the high $\left[\mathrm{CO}_{2}\right]$ damaged mesophyll tissues and inhibited metabolic reaction in the photosynthetic apparatus of the leaves (Graan and Boyer, 1990).

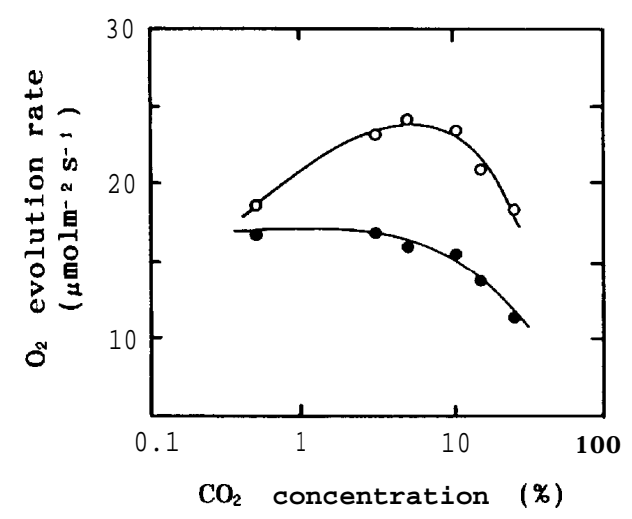

Fig. 1. The effect of $\mathrm{CO}_{2}$ concentration on the oxygen evolution rate in peeled $(-)$ and unpeeled $(O)$ leaf. The horizontal axis is a logarithmic scale.

In a peeled leaf, OER increased slightly with change in $\left[\mathrm{CO}_{2}\right]$ from $0.5 \%$ to $5 \%$, and decreased gradually with further $\left[\mathrm{CO}_{2}\right]$ increase (Fig. 1). It is suggested that the OER of leaf discs with peeled epidermis has been already saturated at $0.5 \%$ [CO,] and metabolic inhibition is detected over $10 \%\left[\mathrm{CO}_{2}\right]$. This also indicates that the saturated values of OER can be measured in the range from $5 \%$ to $10 \%\left[\mathrm{CO}_{2}\right]$, even though the leaf discs have an epidermal barrier to $\mathrm{CO}_{2}$ penetration of photosynthetic tissues. The optimum $\left[\mathrm{CO}_{2}\right]$ for measurements of sweet potato leaves seemed to be about $5 \%$ from results shown in Fig. 1.

When a leaf is exposed to saturating light intensities for a long period of darkness or low light, an induction period (IP) exists before OER has reached a steady -state (McAlisters, 1937; Osterhout and Haas, 1919). The length of IP became shorter by illuminating the leaf before the start of measurement.

Figure 2 shows IP as influenced by pre - illumination periods. In the non preilluminated leaf discs, which had been placed in the dark for $30 \mathrm{~min}$, OER exhibited a short burst during the first 30s after illumination, then decreased for the next $1 \mathrm{~min}$, and began to increase gradually to a maximal steady-state in around $10 \mathrm{~min}$. IP was 


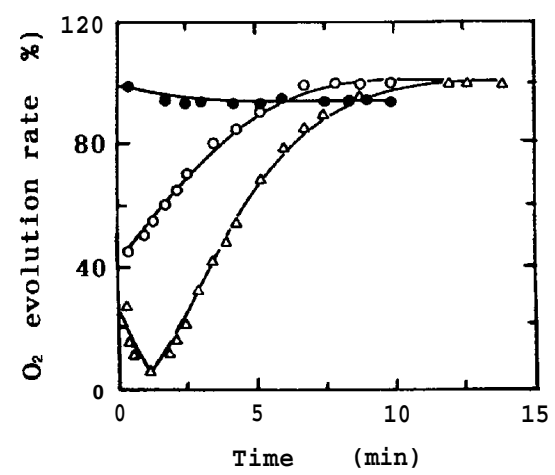

$\mathrm{O}_{2}$ evolution rate

( $\mu \mathrm{molm}^{-2} \mathrm{~s}^{-1}$ )

Fig. 2. The effect of pre-illumination period $(\triangle, 0 ; \mathbf{0}, 3 ; \mathbf{O}, 10$ $\min$ ) on the $\mathrm{O}_{2}$ evolution rate.

shortened with pre-illumination period; no IP was detected in the leaf disc which had been pre-illuminated for $10 \mathrm{~min}$.

Although the mechanisms of the induction requirement for photosynthesis is poorly understood, it has been thought that the initial burst of OER in the pre -darkened leaf shown in Fig. 2 was photochemical reduction of intermediates accumulated in the dark and available for reduction during the first minute of illumination (Prinsley and Leegood, 1986; Robin and Pearcy, 1986). Thus, the length of IP probably requires autocatalytic build up of sufficient pools of carbon reduction cycle metabolites and/or light activation of photosynthetic enzymes.

The high sensitivity and rapid response of this apparatus could be used to study the functional interrelation between photochemical and carbon fixation reactions of photosynthesis in Ipomoea batatas leaves.

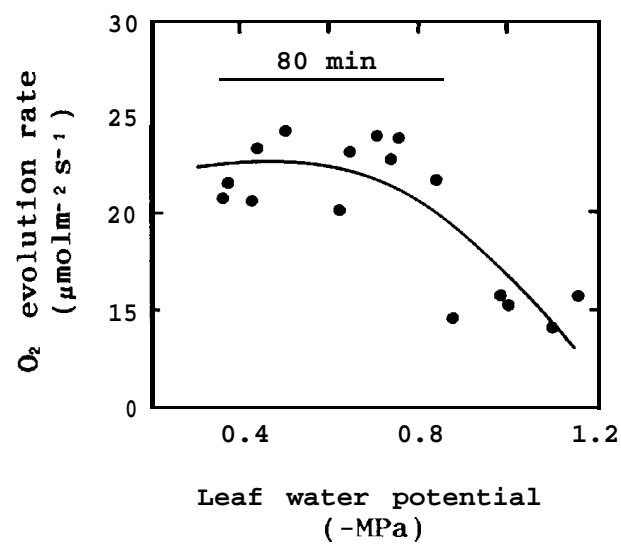

Fig. 3. The relationship between leaf water potential and $\mathrm{O}_{2}$ evolution rate. 
Measurement of OER is made using detached leaf discs and its water content is lost during the measurement. Thus, measurable periods depend on the retention degree of leaf water potential $\left(\psi_{w}\right)$. Fig. 3 shows OER as influenced by decreasing $\psi_{w}$ of leaf discs. The OER was constant for $80 \mathrm{~min}$ when $\psi_{\mathrm{w}}$ was above $-0.8 \mathrm{MPa}$.

As water stress increases, photosynthetic rates are generally reduced by increase in stomata1 resistance and inhibition chloroplast metabolism (Hanson and Hitz, 1982; Kaiser, 1987). In the $\mathrm{O}_{2}$ electrode system, the stomatal limitation can be overcome, and values obtained with the apparatus presumably indicate the activity of chloroplast metabolism. In this study photosynthetic rate of mesophyll tissue began to decrease at $-0.8 \mathrm{MPa}$ (Fig. 3). However, by humidifying the air, the leaf discs can maintain water status adequately for $80 \mathrm{~min}$. This indicates that normal OER, independent of water deficit, can be measured during this time.

Figure 4 shows the relationship between CAR and OER. The CAR was measured with IRGA in an intact peeled leaf and OER was measured with the $\mathrm{O}_{2}$ electrode 'using detached leaf discs at $5 \% \quad\left[\mathrm{CO}_{2}\right]$. There was a significantly $(\mathrm{P}<0.01)$ high correlation between CAR and OER, giving the following regression: [OER] $=5.72+2.49$ [CAR]. The high correlation indicates that the measurements by $\mathrm{O}_{2}$ electrode can present a good coincidence with those of IRGA. The high OER obtained here suggests that the photorespiration is almost completely suppressed under the conditions of high $\left[\mathrm{CO}_{2}\right]$, and thus this OER is regarded as a maximal rate of coupled election transport through both photosystems (Delieu and Walker, 1981; Lilley and Walker, 1975).

In conclusion, it is considered that the gas -phase $\mathrm{O}_{2}$ electrode has a number of advantages in photosynthetic measurement, and can provide useful information for photosynthetic study of Ipomoea batatas leaves.

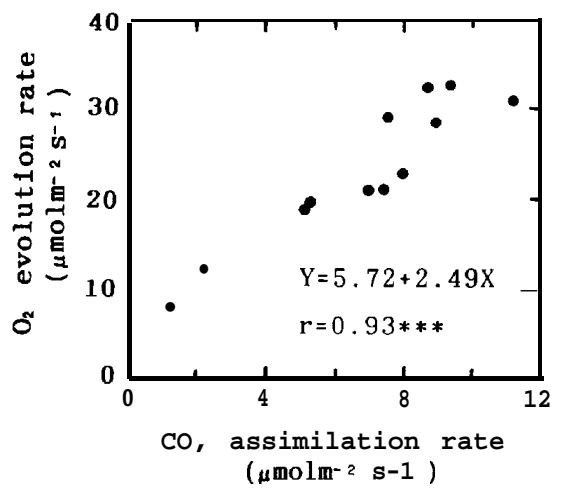

Fig. 4. The relationship between $\mathrm{CO}$, fixation rate and $\mathrm{O}_{2}$ evolution rate in peeled leaf. 


\section{REFERENCES}

Delieu, T. J. and D. A. Walker 1981 Polarographic measurement of photosynthetic $\mathrm{O}_{2}$ evolution by leaf discs. New Phytol., 89: 165-175

Delieu, T. J. and D. A. Walker 1983 Simultaneous measurement of oxygen evolution and chlorophyll fluorescence from leaf pieces. Plant Physiol., 73: 534-541

Gaastra, P. 1959 Photosynthesis of crop plants as influenced by light, carbon dioxide, temperature and stomatal diffusive resistance. Mededel. Landbouwhogesh. Wageningen, 59: 168

Graan, T. and J. S. Boyer 1990 Very high $\mathrm{CO}_{2}$ partially restores photosynthesis in sunflower at low water potentials. Planta, 181: 378-384

Hanson, A. D. and W. D. Hitz 1982 Metabolic responses of mesophytes to plant water deficits. Ann. Rev. Plant Physiol., 33: 163-203

Ishihara, K., R. Sago, T. Ogura, T. Ushijima and T. Tazaki 1972 The relationship between environmental factors and behaviour of stomata in the rice plant. 4. The relation between stomata1 aperture and photosythetic rate. Jpn. J. Crop Sci., 41: 93 - 101 (in Japanese with English summary)

Ishihara, K., E. Kuroda, R.Ishii and T. Ogura 1979 Relationship between nitrogen content in leaf blades and photosynthetic rate in rice plants measured with an infrared gas analyzer and an oxygen electrode. Jpn. J. Crop Sci., 48: 551-556 (in Japanese with English summary)

Ishii, R., T.Yamagishi and Y. Murata 1977 On a method for measuring photosynthesis and respiration of leaf slices with an oxygen electrode. Jpn. J. Crop Sci., 46: 53-57

Jones, H. G. and C. B. Osmond 1973 Photosynthesis by thin leaf slices in solution. I. Properties of leaf slices and comparison with whole leaves. Aust.J.biol. Sci., 26: 15-24

Kaiser, W. M. 1987 Effects of water deficit on photosynthetic capacity. Physiol. Plant., 71: $142-$ 149

Kubota, F., W. Agata and M. Morokuma 1991 Photosynthetic control factors in a single leaf of sweet potato, Ipomoea batatas Lam. I. Leaf epidermis peeling method and photosynthetic rate of peeled leaf. Jpn. J. Crop Sci., 60: 510-514 (in Japanese with English summary)

Lilley, R. McC. and D. A. Walker 1975 Carbon dioxide assimilation by leaves, isolated chloroplasts and ribulose bisphosphate carboxylase from spinach. Plant Physiol., 55: 1087-1092

McAlisters E. D. 1937 Time course of phtosynthesis for a higher plant. Smithson. Misc. Coll,, 95: 117

Osterhout, W. J. V. and R. C. Haas 1919. On the dynamics of photosynthesis. J. Gen. Physiol., 1: 116

Prinsley R. T. and R. C. Leegood 1986 Factors affecting photosynthetic induction in spinach leaves. Biochimica et Biophysica Acta 849: 249-253

Robin, L. C. and R. W. Pearcy 1986 Photosynthetic responses to light variation in rainforest species. I. Induction under constant and fluctuating light conditions. Oecologia 69: 517-523

Yamashita,T., H. Kohda, J. Nanri and G. Tomita 1978 The simultaneous measurement of $\mathrm{O}_{2}$ evolving and $\mathrm{CO}_{2}$-fixing activities in fresh leaves. J. Fac. Agr., Kyushu Univ., 22: 107-118 